\title{
Role of human rhinovirus in triggering human airway epithelial-mesenchymal transition
}

Danielle M. Minor ${ }^{1,2}$ and David Proud ${ }^{1,3^{*}}$ (i)

\begin{abstract}
Background: Structural changes in the airways, collectively referred to as airway remodeling, are a characteristic feature of asthma, and are now known to begin in early life. Human rhinovirus (HRV)-induced wheezing illnesses during early life are a potential inciting stimulus for remodeling. Increased deposition of matrix proteins causes thickening of the lamina reticularis, which is a well-recognized component of airway remodeling. Increased matrix protein deposition is believed to be due to the presence of increased numbers of activated mesenchymal cells (fibroblasts/myofibroblasts) in the subepithelial region of asthmatic airways. The origin of these increased mesenchymal cells is not clear, but one potential contributor is the process of epithelial-mesenchymal transition (EMT). We hypothesized that HRV infection may help to induce EMT.
\end{abstract}

Methods: We used the BEAS-2B human bronchial epithelial cells line, which uniformly expresses the major group HRV receptor, to examine the effects of stimulation with HRV alone, transforming growth factor- $\beta 1$ (TGF- $\beta 1$ ), alone, and the combination, on induction of changes consistent with EMT. Western blotting was used to examine expression of epithelial and mesenchymal phenotypic marker proteins and selected signaling molecules. Cell morphology was also examined.

Results: In this study, we show that two different strains of HRV, which use two different cellular receptors, are each capable of triggering phenotypic changes consistent with EMT. Moreover, both HRV serotypes synergistically induced changes consistent with EMT when used in the presence of TGF- $\beta 1$. Morphological changes were also most pronounced with the combination of HRV and TGF- $\beta 1$. Viral replication was not essential for phenotypic changes. The synergistic interactions between HRV and TGF- $\beta 1$ were mediated, at least in part, via activation of mitogen activated protein kinase pathways, and via induction of the transcription factor SLUG.

Conclusions: These data support a role for HRV in the induction of EMT, which may contribute to matrix protein deposition and thickening of the lamina reticularis in airways of patients with asthma.

Keywords: Human rhinovirus, Epithelial-mesenchymal transition, Transforming growth factor- $\beta 1$, E-cadherin, Fibronectin, MAP kinases, SLUG

\footnotetext{
*Correspondence: dproud@ucalgary.ca

'Department of Physiology \& Pharmacology, Snyder Institute for Chronic Diseases, Cumming School of Medicine, University of Calgary, Calgary, Alberta, Canada

${ }^{3}$ Department of Physiology \& Pharmacology, HRIC 4AC60, University of Calgary Cumming School of Medicine, 3280 Hospital Drive NW, Calgary, Alberta T2N 4Z6, Canada

Full list of author information is available at the end of the article
} 


\section{Background}

The airways of patients with asthma display a number of characteristic structural changes that are collectively referred to as airway remodeling. These structural changes include an increase in airway smooth muscle mass, goblet cell hyperplasia/metaplasia leading to increased mucus production, epithelial fragility [1, 2], and increased numbers of fibroblasts and myofibroblasts in the subepithelial region that are associated with increased extracellular matrix protein deposition and thickening of the lamina reticularis $[3,4]$.

Although it was long thought that airway remodeling developed only after years of disease expression, bronchial biopsy studies have now established that components of airway remodeling can be demonstrated in early childhood, even prior to the formal diagnosis of asthma being made [5]. Several studies have demonstrated features of airway remodeling, including thickening of the lamina reticularis, increased smooth muscle mass, increased mucus gland area and angiogenesis in pre-school age children [6-9]. Interestingly, such features were not observed in symptomatic infants with reversible airflow obstruction [10]. This suggests that airway remodeling occurs in response to some inciting stimulus (or stimuli) in early life, and is not a congenital phenomenon.

Human rhinovirus (HRV) infections in early life are a common trigger for childhood wheezing illnesses [11, 12], and HRV-induced wheezing illnesses in the first 3 years of life are a major risk factor for subsequent development of asthma [13]. Longitudinal analysis has shown that preschool age children have about six HRV infections per year [14], and serial viral infections can lead to recurrent wheezing episodes [15]. Given the concurrent time frame of recurrent HRV-induced wheezing episodes and the development of $A R$, it is possible that HRV infections may be one stimulus that could contribute to the initiation and progression of airway remodeling in asthma.

The human airway epithelial cell is the primary site of HRV infection and previous studies have shown that infected epithelial cells release a number of growth factors and proteins linked to airway remodeling [16-18]. The epithelium has also been suggested as a potential source of the increased numbers of mesenchymal cells in the airways during a number of disease conditions through the process of epithelial to mesenchymal transition (EMT), in which typical epithelial phenotypic proteins and morphology are lost and features of mesenchymal cells are acquired [19-22]. In the current studies, we tested the hypothesis that HRV infection of airway epithelial cells could contribute to airway remodeling by inducing EMT. Moreover, because the cytokine transforming growth factor- $\beta$ (TGF- $\beta$ ) has been described to be a key mediator of EMT in human epithelial cells [20, 23], and is present in increased amounts in asthmatic airways [24, 25], we also examined potential interactions of HRV with TGF- $\beta$ in inducing EMT.

\section{Methods \\ Epithelial cell culture}

Major group HRV species, which use intercellular adhesion molecule-1 (ICAM-1) as a receptor, do not infect more than $5-10 \%$ of primary human bronchial epithelial cells in culture [26]. Therefore, we chose to perform the current studies using the BEAS-2B human bronchial epithelial cell line, which uniformly expresses ICAM-1 [27]. This cell line was derived [28], and kindly provided by Dr. Curtis Harris (NCI, Bethesda, MD). The BEAS-2B cell line has been widely used in the literature to study EMT [23, 29-31], as well as epithelial response to HRV [18, 32-34]. BEAS-2B cells were cultured in Bronchial Epithelial Basal Medium (BEBM) (Lonza, Walkersville, MD) supplemented with bovine pituitary extract, epidermal growth factor, epinephrine, gentamicin and amphotericin B, hydrocortisone, insulin, trans-retinoic acid, transferrin, and triiodothyronine to make Bronchial Epithelial Growth Medium (BEGM) on 6-well culture plates at $37^{\circ} \mathrm{C}$ and $5 \% \mathrm{CO}_{2}$.

\section{HRV generation and purification}

Two serotypes of HRV were used, both of which are members of the HRV-A group. Stocks of major group HRV-16, or of minor group HRV-1A, which uses members of the low-density lipoprotein receptor (LDLR) family for cell entry, were originally obtained from American Type Culture Collection (Rockville, MD). HRV-16 was propagated in WI-38 fetal lung fibroblasts cells (American Type Culture Collection, Rockville, $\mathrm{MD})$, while minor group HRV-1A was propagated in H1-HeLa cells (American Type Culture Collection, Rockville, MD). Both strains of HRV were purified by sucrose density centrifugation to remove ribosomes and soluble factors as previously described [35, 36]. Viral titers were determined by using WI-38 or H1-HeLa cells grown in 96-well plates as previously described [36].

\section{Treatment of epithelial cell culture}

When cells achieved $60 \%$ confluence, culture medium was removed and replaced with BEGM from which hydrocortisone had been removed (BEGM no HC), for 24 hours prior to stimulation. Fresh BEGM no $\mathrm{HC}$ was then added and BEAS-2B cells were infected with $10^{4.5} 50 \%$ tissue culture-infective dose $\left(\mathrm{TCID}_{50}\right) \mathrm{U} / \mathrm{ml}$ of either purified HRV-16 or purified HRV-1A alone, $10 \mathrm{ng} / \mathrm{ml}$ recombinant TGF- $\beta_{1}$ (R\&D Systems, Minneapolis, MN), or the combination of each HRV and TGF- $\beta_{1}$, and subsequently incubated at $34{ }^{\circ} \mathrm{C}$ in $5 \% \mathrm{CO}_{2}$ for specified time points. In 120-hour experiments, the medium and TGF- $\beta_{1}$ were replaced at 48 and 96 hours. We demonstrated that treatment with HRV alone, TGF- $\beta_{1}$ alone, or the combination, 
did not reduce cell viability using the 3-(4,5-dimethylthiazol-2-yl)-2,5-diphenyl tetrazolium bromide (MTT) viability assay (data not shown). For studies examining activation of mitogen activated protein kinase (MAPK) signaling pathways, BEAS-2B cells were pretreated for 24 hours in BEGM no $\mathrm{HC}$ then placed in BEBM for one hour prior to experiment treatment to reduce basal activation. BEBM was used for treatment medium.

\section{Replication-deficient HRV}

To render HRV replication-deficient, stocks of purified HRV-16 and HRV-1A were exposed for 5 min to a Spectroline Model XX-15 F high intensity short wavelength (254 nm) ultra-violet (UV) lamp (Spectronics Corp., Westbury, NY) at a distance of $5 \mathrm{~cm}$. It was confirmed that treated virus was replication-deficient by showing that the ability to cause lysis in appropriate host cells (WI-38 or H1-HeLa) was lost. UV-treated virus was used in experiments at doses identical to those for intact (replication competent) HRV in all experiments.

\section{Pharmacological Inhibitors}

Commercially available pharmacological inhibitors, SB203580 and PD95089 from InvivoGen (San Diego, CA), were used to inhibit p38 MAPK and MEK1/MEK2 (ERK 1/2) MAPK pathways, respectively. For these studies, BEAS-2B cells were pretreated with the inhibitor of interest for 1 hour prior to addition of HRV-16, HRV$1 \mathrm{~A}$, TGF- $\beta_{1}$, and the combination of each HRV serotype with TGF- $\beta_{1}$. Cells were harvested for whole-cell lysates at 24 hours.

\section{Whole-cell lysates}

Post infection, BEAS-2B cells were lysed in ice-cold lysis buffer (1\% Triton X-100 in 1 X MES buffered saline $\mathrm{pH} 7.4$, containing anti-protease tablets, $50 \mathrm{nM}$ sodium orthovanadate, $0.4 \mathrm{M}$ sodium pyrophosphate, and $1 \mathrm{M}$ sodium fluoride). Lysates were analyzed for protein content using a DC Protein Assay (BioRad Laboratories, Mississauga, ON, Canada) as manufacturer recommended.

\section{Western blots}

Equivalent amounts of whole cell lysate were separated by $10 \%$ SDS-PAGE, and then transferred to a $0.45 \mu \mathrm{m}$ nitrocellulose membrane. Membranes were blocked with $5 \%$ skim milk, and incubated overnight at $4{ }^{\circ} \mathrm{C}$ with the following antibodies: E-cadherin (BD Biosciences, San Jose, CA), cytokeratin-18 and cellular fibronectin (both from Sigma-Aldrich, Oakville, ON, Canada), vimentin, phospho-ERK1/2 mitogen activated protein kinase (MAPK), total-ERK1/2 MAPK, phospho-p38 MAPK, total-p38 MAPK, SLUG, SNAIL, or phospho-SMAD 2/3 (all from Cell Signaling, Danvers, MA). Membranes were then stripped and re-probed for the housekeeping protein, $\beta$-tubulin (Sigma-Aldrich, Oakville, ON, Canada).

\section{Densitometry analysis}

Densitometry analysis was performed using ImageJ software (version 1.41, National Institute of Health, Bethesda, MD). The fold change in expression of the protein of interest was determined by normalizing the raw pixel count of the protein of interest to the raw pixel count of the respective housekeeping protein. This was then compared to the normalized value for medium control. Data is expressed as fold change over medium control unless specified otherwise.

\section{Assessment of morphological changes}

To determine the percentage of cells exposed to each treatment that acquired a mesenchymal morphology, we used ImageJ software to measure the length and width of 75 BEAS-2B cells grown under normal medium conditions. The mean and standard deviation of the length to width ratio was then calculated for these 75 cells. We then calculated the mean length to width ratio +10 standard deviations and established this number as a threshold that must be exceeded before a cell was considered sufficiently long and thin (spindle-like) to be classified as of a mesenchymal morphology. Using a grid reticule, we then used the same software to count a minimum of 50 cells from each treatment condition in each of three separate experiments and calculate the percentage of cells (mean \pm SEM) that showed a mesenchymal phenotype in response to each treatment.

\section{Statistical analysis}

All statistics were performed using GraphPad Prism 6 (GraphPad Software, CA). Data is presented as mean \pm standard error of the mean. Non-Gaussian distributed data was analyzed by Kruskal-Wallis one-way analysis of variance (ANOVA) with Dunn's post hoc analysis. Synergy between groups was determined by summing the values obtained in response to each individual treatment per experiment, and comparing that to the value obtained in response to the combined treatment using Wilcoxon matched-pairs analysis. For all statistical tests, a two-tailed $p$ value of 0.05 was considered significant.

\section{Results}

Purified HRV-16 causes phenotypic changes characteristic of EMT in BEAS-2B cells, both alone and in combination with TGF- $\beta_{1}$

Because it has previously been reported that $120 \mathrm{~h}$ of stimulation with TGF- $\beta$ induces changes in epithelial phenotype consistent with EMT [23], we chose this time for our initial experiments. We initially confirmed that none of the treatments used affected cell viability under 
our experimental conditions, as assessed by the MTT assay (data not shown). We examined expression of the epithelial phenotypic marker proteins, E-cadherin and cytokeratin-18, as well as of the mesenchymal phenotypic marker proteins, cellular fibronectin (including EDA fibronectin) and vimentin, using western blot and densitometry. In BEAS-2B cells exposed to HRV-16, we observed a significant reduction in expression of Ecadherin (Fig. 1a and b), as well as in expression of cytokeratin-18, (Fig. 1c and d). Surprisingly, by contrast, cells exposed to TGF- $\beta_{1}$ alone showed no significant reduction in the expression of either of these epithelial marker proteins. Interestingly, when cells were exposed to the combination of HRV-16 and TGF- $\beta_{1}$ a striking synergistic loss of both epithelial marker proteins was observed (Fig. 1b and d).

Because other studies have indicated that TGF- $\beta_{1}$ alone is able to trigger the loss of epithelial markers in both BEAS-2B cells and primary human airway epithelial cells, we used another TGF receptor ligand, activin A, to examine loss of E-cadherin. Consistent with our data using TGF- $\beta_{1}$, activin A also failed to significantly reduce E-cadherin expression but, like TGF- $\beta_{1}$ synergistically induced loss if E-cadherin when used in combination with HRV (Fig. 2)

Although exposure of BEAS-2B cells to HRV-16 was effective in triggering the loss of expression of epithelial marker proteins, HRV-16 alone did not significantly induce expression of the mesenchymal markers fibronectin (Fig. 3a and b), or vimentin (Fig. 3c and d). By contrast, exposure to TGF- $\beta_{1}$ alone led to significant induction of both fibronectin and vimentin when compared to medium control (Fig. 3a-d). When cells were exposed to the combination of HRV-16 and TGF- $\beta_{1}$ a synergistic induction of fibronectin was observed (Fig. 3b). The increase in vimentin expression was also greatest with the combination of HRV-16 and TGF- $\beta_{1}$, but it did not achieve statistical significance for synergy (Fig. 3d).

In addition to examining the expression of phenotypic marker proteins $120 \mathrm{~h}$ after exposure to each stimulus alone or in combination, we also examined cellular morphology. Compared to cells cultured in medium

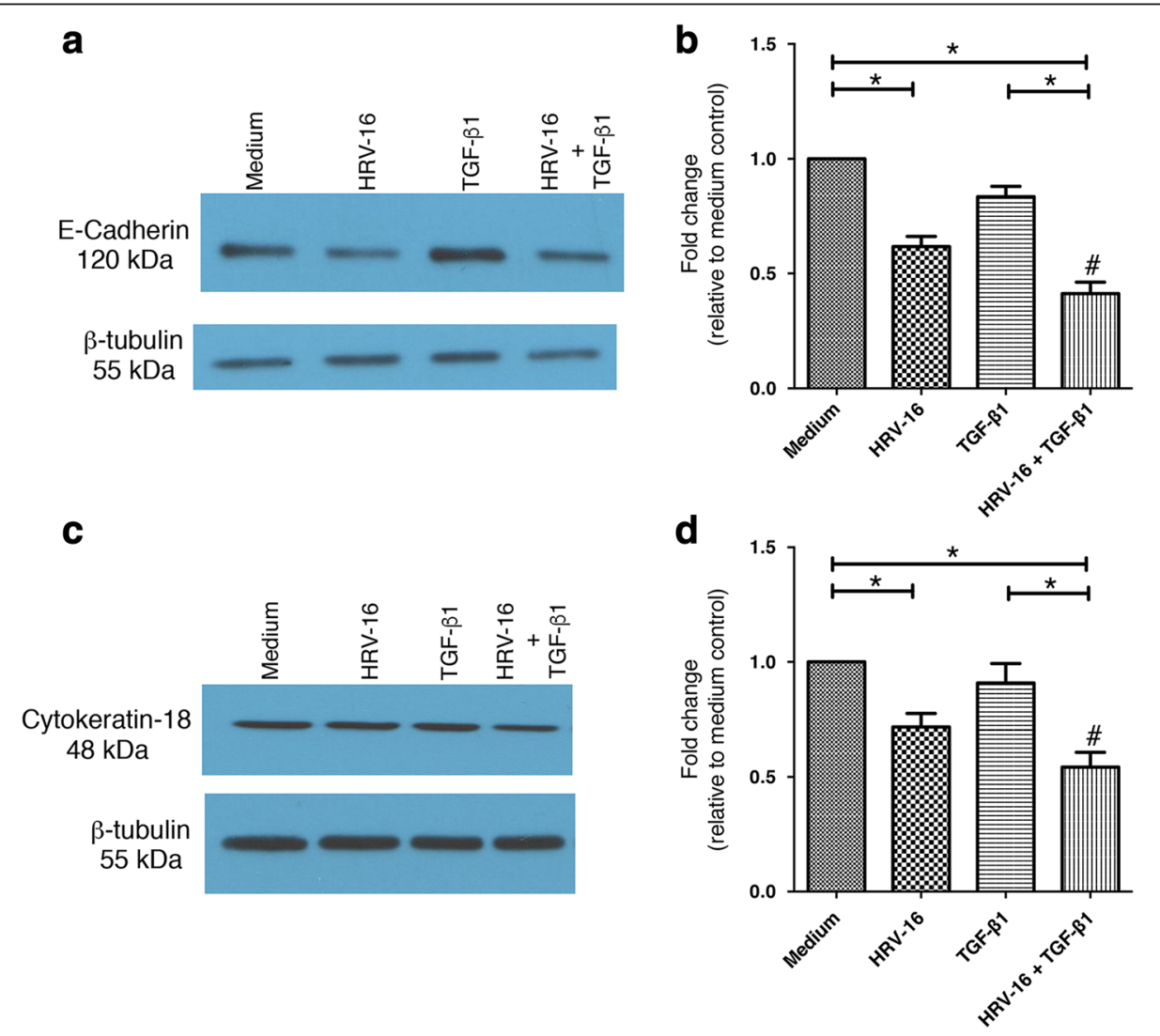

Fig. 1 Effects of exposure for $120 \mathrm{~h}$ to HRV-16 alone, TGF- $\beta_{1}$ alone, and the combination on expression of epithelial markers in BEAS-2B cells. BEAS-2B cells were incubated with medium alone (labeled medium in Figures), HRV-16, TGF- $\beta_{1}$, and HRV-16 + TGF- $\beta_{1}$ for 120 h. a Representative western blot for E-cadherin. b Densitometry analysis for E-cadherin $(n=11)$. c Representative western blot for Cytokeratin-18. d Densitometry analysis for Cytokeratin-18 $(n=11)$. Asterisk indicates significance for comparisons shown by Dunn's post-hoc analysis after Kruskal-Wallis ANOVA. Hatchmark indicates synergy compared to the sum of responses to individual stimuli by Wilcoxon matched-pairs signed ranks test 

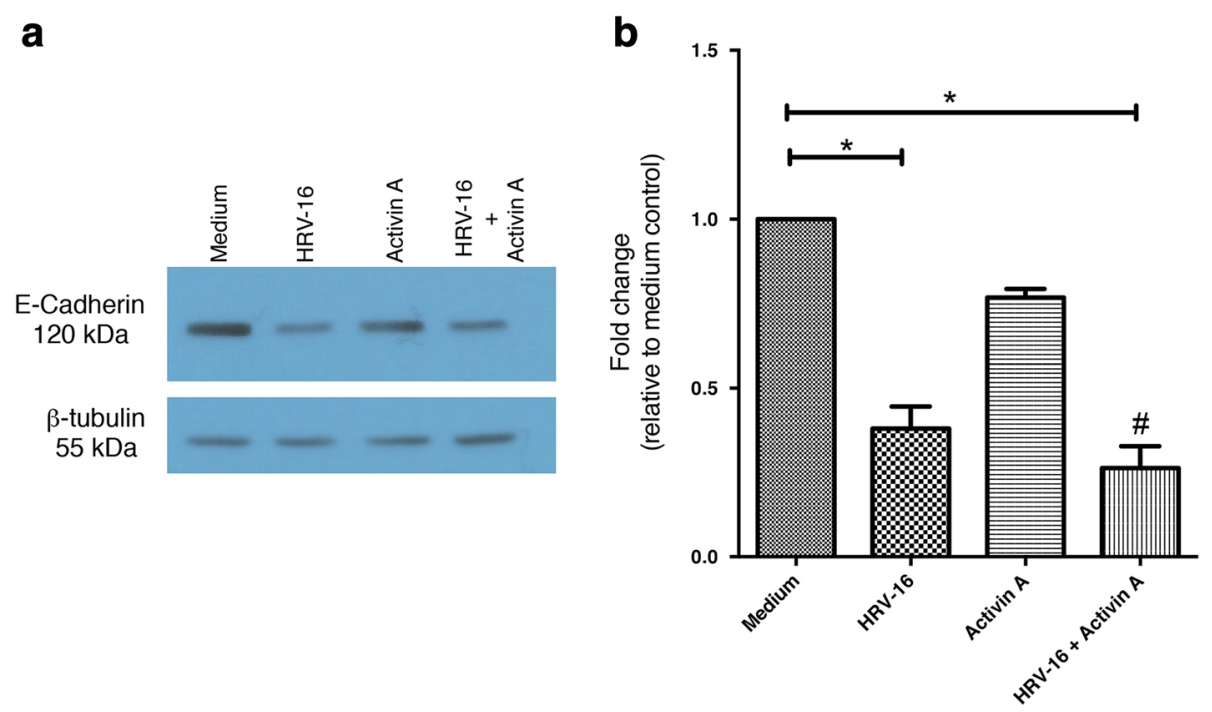

Fig. 2 Effects of exposure for $120 \mathrm{~h}$ to HRV-16 alone, Activin A alone, and the combination on expression of E-cadherin in BEAS-2B cells. BEAS-2B cells were incubated with medium alone, HRV-16, Activin A, and HRV-16+TGF- $\beta_{1}$ for 120 h. a Representative western blot for E-cadherin. b Densitometry analysis for E-cadherin $(n=6)$. Asterisk indicates significance for comparisons shown by Dunn's post-hoc analysis after Kruskal-Wallis ANOVA. Hatchmark indicates synergy compared to the sum of responses to individual stimuli by Wilcoxon matched-pairs signed ranks test

alone, exposure to either HRV-16 alone or to TGF- $\beta_{1}$ alone caused modest changes in morphology (Fig. 4a-c). Exposure to the combination of HRV-16 and TGF- $\beta_{1}$, however, induced substantially more cells to adopt a spindle-like morphology consistent with that of fibroblasts or myofibroblasts (Fig. 4d). To quantify the extent of mesenchymal morphology, we calculated the mean \pm standard deviation of the length to width ratio of 75 epithelial cells grown in medium. We added $10 \mathrm{x}$ the standard deviation to the mean ratio and used this as a threshold to define mesenchymal morphology. We then calculated the percentage of mesenchymal cells under each experimental condition in three experiments. By definition there were no mesenchymal cells in the cells grown in medium alone. HRV-16 exposure alone caused $6 \pm 3 \%$ of cells to adopt a mesenchymal morphology, while TGF- $\beta_{1}$ alone induced $2 \pm 1.1 \%$ of cells to become mesenchymal in shape. Neither of these was significantly increased above control. The combination of HRV-16 and TGF- $\beta_{1}$, however, caused $25.3 \pm 7.6 \%$ of cells to adopt a mesenchymal morphology, a significant increase above medium alone, and above each of the other two treatment groups (Fig. 4e).

\section{Phenotypic protein alterations occur within $24 \mathrm{~h}$ of exposure of BEAS-2B cells to HRV-16, or HRV-16 with TGF- $\beta_{1}$}

In order to determine how early after exposure to stimuli changes in phenotypic marker proteins could be observed, whole cell lysates of BEAS-2B cells treated with
HRV-16, TGF- $\beta_{1}$, or the combination, were harvested every $24 \mathrm{~h}$ throughout 120 hour treatment period. Because they had given the greatest "signal-to-noise" response at $120 \mathrm{~h}$, the epithelial marker, E-cadherin, and the mesenchymal marker, fibronectin, were used as readouts of EMT. Later time points are not shown because, by $24 \mathrm{~h}, \mathrm{BEAS}-2 \mathrm{~B}$ cells treated with HRV-16 alone or in combination with TGF- $\beta_{1}$ already showed a significant reduction in expression of E-cadherin (Fig. 5a and b). Once again, treatment with the combination of HRV-16 and TGF- $\beta_{1}$ induced a loss of E-cadherin expression that was synergistic compared to the sum of the responses to HRV-16 alone and TGF- $\beta_{1}$ alone. Similarly, 24 h exposure to TGF- $\beta_{1}$, alone or in combination with HRV-16, led to a significant induction of the mesenchymal protein fibronectin (Fig. $5 \mathrm{c}$ and d). Although the combination of HRV-16 and TGF- $\beta_{1}$ induced the greatest expression of fibronectin, this was not synergistic compared to the sum of the responses to each stimulus alone. Morphologic changes in BEAS-2B cells began to be observed at $48 \mathrm{~h}$ post-treatment. The altered expression of E-cadherin and fibronectin observed within $24 \mathrm{~h}$ raised the possibility that early signaling events may play a role in driving observed protein and morphological alterations in BEAS-2B cells.

\section{Viral replication is not essential in causing changes associated with EMT}

To determine if viral replication was essential for the induction of changes consistent with EMT, BEAS-2B cells 

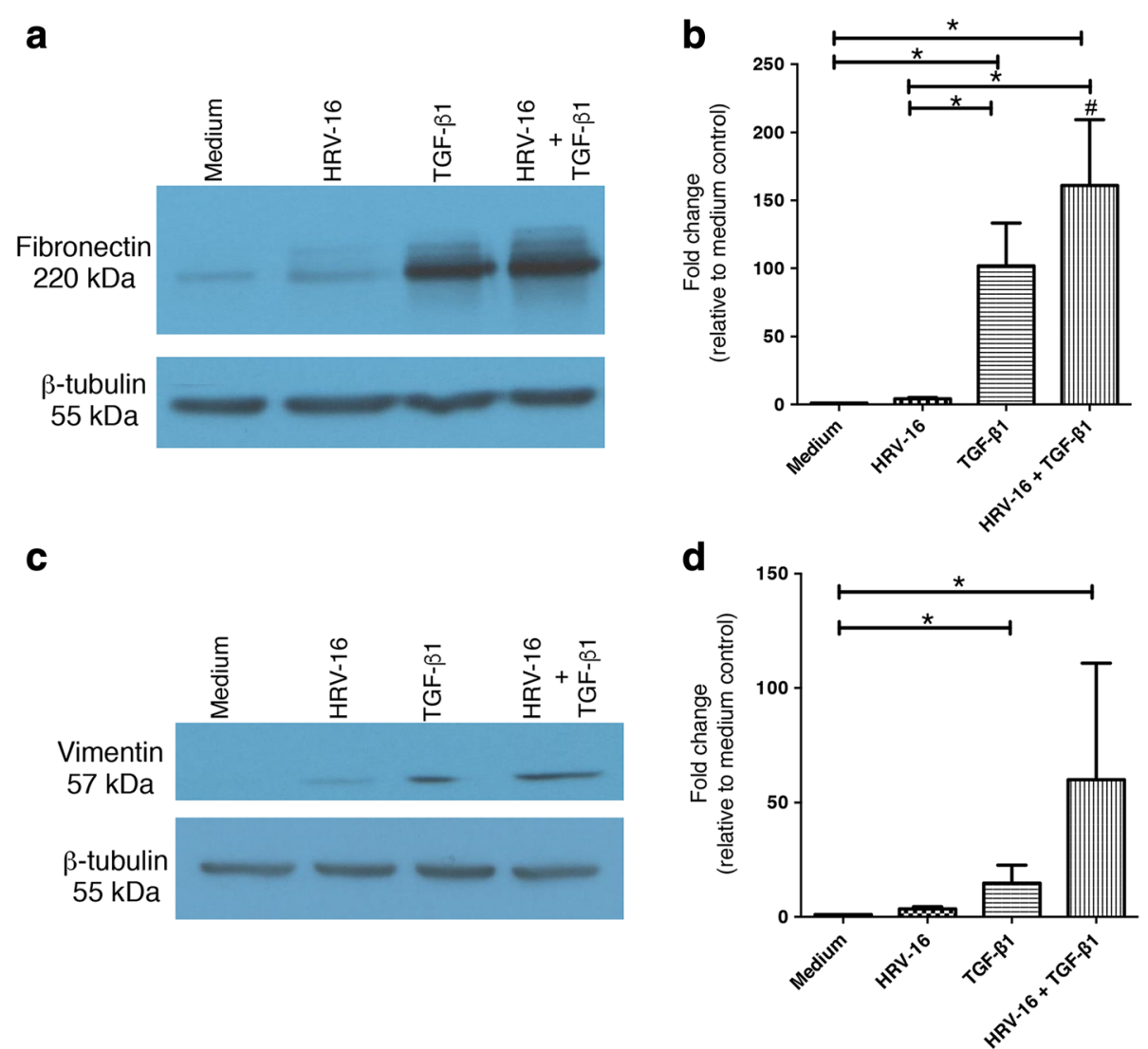

Fig. 3 Effects of exposure for $120 \mathrm{~h}$ to HRV-16 alone, TGF- $\beta_{1}$ alone, and the combination on expression of mesenchymal markers in BEAS-2B cells. BEAS-2B cells were stimulated with medium, HRV-16, TGF- $\beta_{1}$, and HRV- $16+$ TGF- $\beta_{1}$ for $120 \mathrm{~h}$. a Representative western blot for fibronectin. $\mathbf{b}$ Densitometry analysis for fibronectin $(n=11)$. $\mathbf{c}$ Representative western blot for vimentin. $\mathbf{d}$ Densitometry analysis for vimentin $(n=11)$. Asterisk indicates significance for comparisons shown by Dunn's post-hoc analysis after Kruskal-Wallis ANOVA. Hatchmark indicates synergy compared to the sum of responses to individual stimuli by Wilcoxon matched-pairs signed ranks test

were exposed for $120 \mathrm{~h}$ to replication-deficient, UVtreated HRV-16, alone or in combination with TGF- $\beta_{1}$. We have previously shown that virus treated in this way is still able to interact with ICAM-1, and to induce receptor-dependent signaling [37]. Treatments using intact, replication-competent, HRV-16 were included as a positive control. UV-treated HRV-16 alone, or in combination with TGF- $\beta_{1}$, significantly reduced E-cadherin expression (Fig. 6a and b), with the combination treatment causing a synergistic reduction of expression compared to the sum of responses of the individual treatments. UV-treated HRV-16 alone, like intact HRV16 alone, did not induce significant expression of the mesenchymal marker fibronectin. When used in combination with TGF- $\beta_{1}$, however, UV-treated HRV-16 caused a synergistic induction of fibronectin that was comparable to that seen with intact HRV-16 + TGF- $\beta_{1}$ (Fig. $6 \mathrm{c}$ and $\mathrm{d}$ ). These results demonstrate that viral replication is not essential to cause phenotypic alterations characteristic of EMT, implying a potential role for viral receptor-mediated signaling.
The minor group rhinovirus serotype, HRV-1A, causes phenotypic alterations indicative of EMT

HRV-16 is a major group HRV, which uses ICAM-1 as its receptor. To determine if responses were selective for this group of rhinoviruses, we examined if HRV-1A, a minor group HRV that uses LDLR as its receptor, could also induce phenotypic changes consistent with EMT. BEAS$2 \mathrm{~B}$ cells were exposed for $120 \mathrm{~h}$ to both replication competent and replication deficient (UV-treated) HRV-1A both alone, and in combination with TGF- $\beta_{1}$. HRV-1A, both alone and in combination with TGF- $\beta_{1}$, caused a significant reduction in expression of E-cadherin (Fig. 7a and b) protein expression. UV-treated HRV-1A alone caused reductions in expression of E-cadherin, but these did not achieve statistical significance. A significant reduction in E-cadherin was observed, however, for the combination of UV-HRV-1A and TGF- $\beta_{1}$. In the case of both HRV-1A and UV-HRV-1A, a synergistic reduction was observed when used in combination with TGF- $\beta_{1}$, compared to the sum of individual responses. Similar trends were also seen when cytokeratin-18 was examined (not shown). 


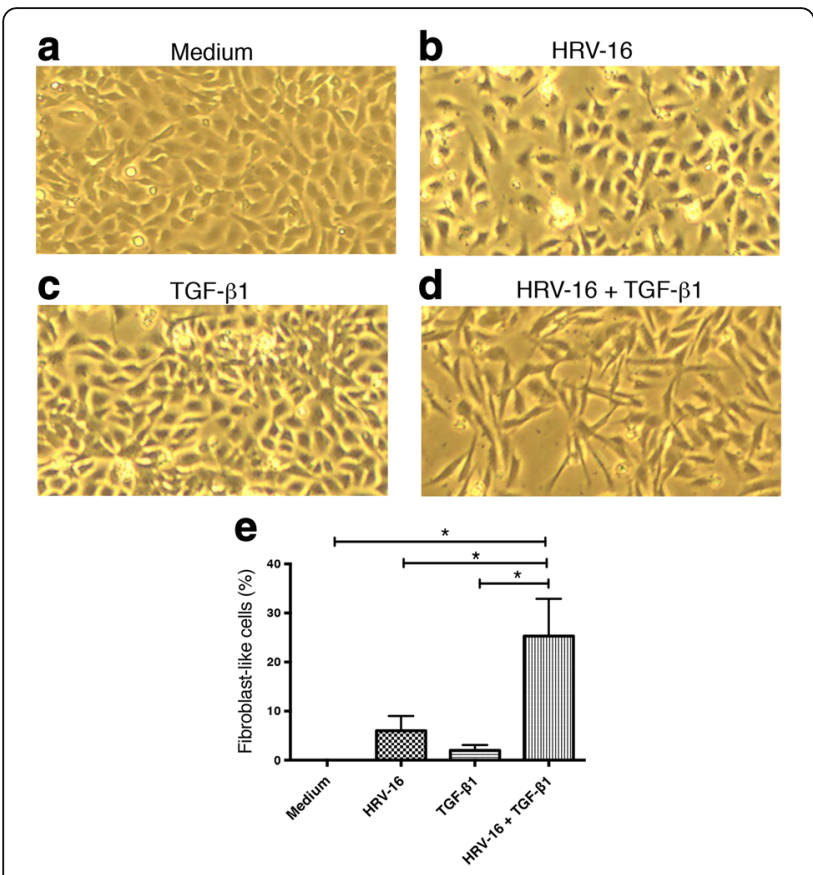

Fig. 4 Effects of exposure for $120 \mathrm{~h}$ to HRV-16 alone, TGF- $\beta_{1}$ alone, and the combination on morphology of BEAS-2B cells. BEAS- $2 B$ cells were stimulated with medium, HRV-16, TGF- $\beta_{1}$, and HRV-16 + TGF- $\beta_{1}$ for $120 \mathrm{~h}$. Light microscopy images (4X magnification) showing representative morphology of cells exposed to $\mathbf{a}$ medium. $\mathbf{b}$ HRV-16 alone. c TGF- $\beta_{1}$ alone. $\mathbf{d}$ The combination of HRV-16 + TGF- $\beta_{1}$. Data are from one of 3 experiments used for quantitative analysis. e Quantitative analysis of percentage of cells with fibroblast-like morphology (mean \pm SEM from 3 experiments). Asterisk indicates significance for comparisons shown by Dunn's post-hoc analysis after Kruskal-Wallis ANOVA

As for HRV-16, HRV-1A alone was not an effective stimulus for induction of mesenchymal markers. Exposure to TGF- $\beta_{1}$ alone induced significant expression of fibronectin, and this was synergistically enhanced when TGF- $\beta_{1}$ was combined with either HRV-1A or UV-HRV1A (Fig. 7c and d). Similar data were also observed when expression of vimentin was examined (not shown). Thus, both major and minor group HRV serotypes are able to induce changes consistent with EMT and, in both cases, HRV can synergize with TGF- $\beta_{1}$ to trigger changes in marker proteins.

\section{Role of P38 and ERK1/2 MAPK Pathways in EMT}

Given that viral replication was not essential for either HRV-16 or HRV-1A to contribute to EMT, we chose to investigate early, receptor-mediated signaling pathways that may contribute to responses. Although several studies have examined early signaling pathways linked to binding of major group HRV to ICAM-1 [37-40], little is known regarding signaling of minor group HRV members via LDLR. HRV-16 interactions with ICAM-1 are known to activate both p38 and ERK1/2 MAPK signaling [37, 41, 42], so we investigated the potential role of these pathways in EMT. Initially, we examined activation of these pathways by each strain of HRV and by TGF- $\beta_{1}$, alone and in combination. Although each strain of HRV alone, or TGF- $\beta_{1}$ alone, induced phosphorylation of p38 MAPK (Fig. 8a and b), only the combinations of either virus strain and TGF- $\beta_{1}$ led to a statistically significant activation. The response to these combinations of HRV and TGF- $\beta_{1}$ appeared to be approximately additive when compared to response to each stimulus alone. TGF- $\beta_{1}$ alone was ineffective in activating the ERK1/2 MAPK pathway. As previously reported, HRV-16 caused robust activation of the ERK1/2 pathway $[41,42]$, and this was not significantly enhanced when combined with TGF- $\beta_{1}$ (Fig. $8 \mathrm{c}$ and $\mathrm{d}$ ). Interestingly, HRV-1A was a less robust activator of the ERK1/2 pathway compared to HRV-16. ERK1/2 activation by HRV$1 \mathrm{~A}$ was also not further increased in combination with TGF- $\beta_{1}$.

To determine if activation of these MAPK pathways may contribute to EMT-like changes in BEAS-2B cells, we used the pharmacological inhibitors SB203580 and PD98059 to inhibit the p38 and ERK 1/2 MAPK pathways, respectively. Given that morphological changes in BEAS$2 \mathrm{~B}$ did not begin to be observed until $48 \mathrm{~h}$ after treatments, we examined expression of phenotypic marker proteins as an outcome measure. Because fibronectin gave the largest signals in our earlier experiments, we selected this protein as the read out of phenotypic changes. The p38 pathway inhibitor, SB203580, significantly decreased the induction of fibronectin expression by HRV-16 alone, HRV-1A alone, and most strikingly, by the combination of each virus with TGF- $\beta_{1}$ (Fig. 9a-d). Blocking the ERK1/2 MAPK pathway using PD95089 significantly inhibited the induction of fibronectin by the combination of HRV-16 and TGF- $\beta_{1}$, while having little to no effect on the modest responses to either stimulus alone (Fig. 10a and b). Conversely, PD98059 enhanced fibronectin induction in response to HRV-1A alone or in combination with TGF$\beta_{1}$ (Fig. 10c and d).

HRV and TGF- $\beta_{1}$ both induce expression of the E-cadherin transcriptional repressor, SLUG

Given the ability of HRV-16 and HRV-1A to synergize with TGF- $\beta 1$ to cause phenotypic changes characteristic of EMT in BEAS-2B cells, we examined whether HRV could modulate known signaling pathways linked to TGF$\beta_{1}$ receptor signaling. We examined modulation of the transcription factors, SLUG and SNAIL, as well as activation of SMAD2/3. BEAS-2B cells were stimulated with HRV-16 alone, TGF- $\beta_{1}$ alone, HRV-16 + TGF- $\beta_{1}$, HRV-1A alone, and HRV-1A + TGF- $\beta_{1}$ for 6 hours and whole cell lysates were analyzed. Although induction of SLUG by 

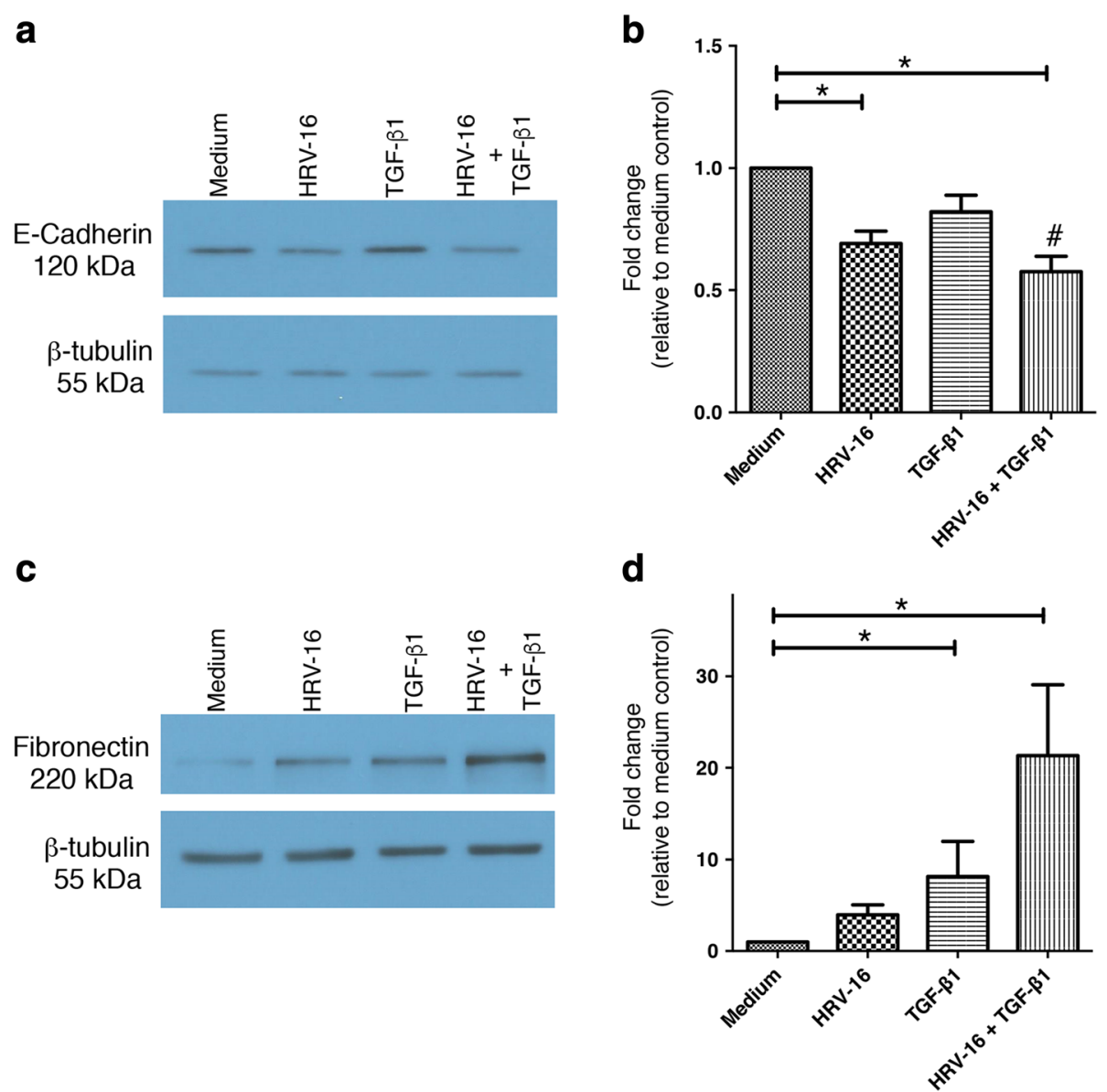

Fig. 5 Exposure for $24 \mathrm{~h}$ to HRV-16 alone, TGF- $\beta_{1}$ alone, and the combination alters expression of epithelial and mesenchymal markers in BEAS2B cells. BEAS-2B cells were stimulated with medium, HRV-16, TGF- $\beta_{1}$, and HRV-16 + TGF- $\beta_{1}$ for $24 \mathrm{~h}$. a Representative western blot for E-cadherin. b Densitometry analysis for E-cadherin $(n=10)$. c Representative western blot for fibronectin. $\mathbf{d}$ Densitometry analysis for fibronectin $(n=10)$. Asterisk indicates significance for comparisons shown by Dunn's post-hoc analysis after Kruskal-Wallis ANOVA. Hatchmark indicates synergy compared to the sum of responses to individual stimuli by Wilcoxon matched-pairs signed ranks test

HRV-16 alone or HRV-1A alone did not achieve statistical significance by post-hoc analysis after ANOVA, both HRV serotypes induce significantly ( $\mathrm{p}<0.02$ in each case) increased in SLUG expression compared to control by appropriate paired analyses. As expected, TGF- $\beta_{1}$ alone also induced expression of SLUG, but expression was markedly increased in response to the combinations of HRV-16+ TGF- $\beta_{1}$ and HRV-1A + TGF- $\beta_{1}$ to levels that were at least additive compared to responses to individual stimuli (Fig. 11a and b). As expected, TGF- $\beta_{1}$ also induced expression of SNAIL. By contrast, neither HRV-16 alone or HRV-1A alone induced significant expression of SNAIL and the combination of each strain of HRV with TGF- $\beta_{1}$ caused no additional activation above that seen with TGF$\beta_{1}$ alone (Fig. 11c and d). Similarly, neither HRV-16 alone nor HRV1A-alone induced phosphorylation of SMAD2/3, and the combination of either HRV serotype with TGF- $\beta_{1}$ caused no activation above that observed with TGF- $\beta_{1}$ alone (Fig. 11e and f).

\section{Discussion}

Recurrent HRV-induced wheezing illnesses in the first 3 years of life are a major risk factor for subsequent development of asthma [13]. Given that this time frame also coincides with the development of airway remodeling, we hypothesized that HRV infections may contribute to aspects of airway remodeling by altering epithelial cell biology. We, and others, have previously shown that HRV infection of human airway epithelial cells, both in vitro and in vivo, can lead to the induction of a number of growth factors linked to airway remodeling [16-18], as well as of chemotactic agents that can cause migration of mesenchymal cells towards the epithelial layer [43]. We now provide direct evidence that two different serotypes of HRV are also able to drive epithelial phenotypic and morphological changes that are indicative of EMT, further supporting a potential role of HRV infections in airway remodeling. Our data contrast somewhat with a 


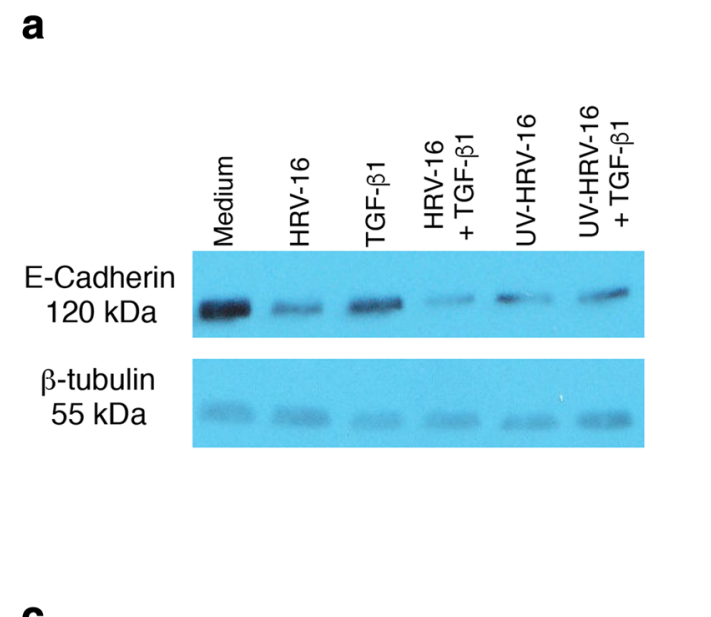

C

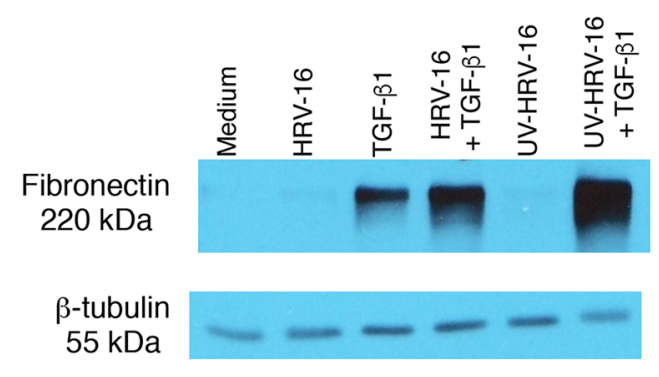

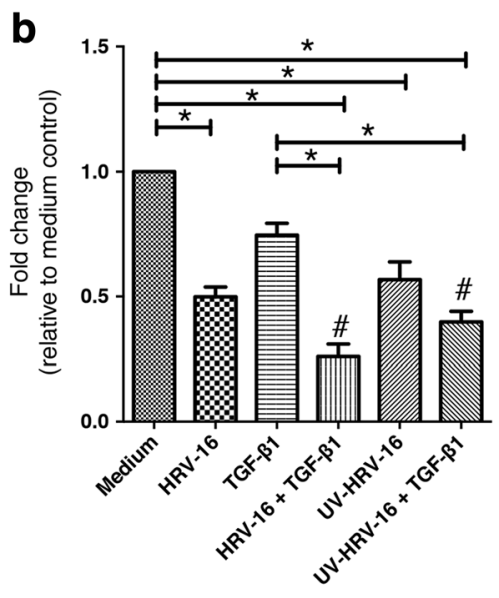

d

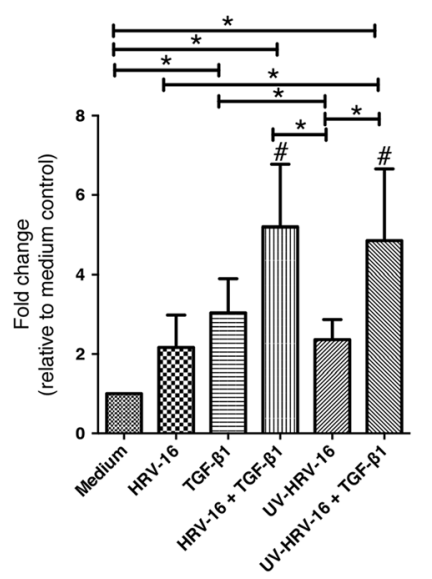

Fig. 6 Viral replication is not essential for HRV-16 alone, or in combination with TGF- $\beta_{1}$, to alter expression of epithelial and mesenchymal markers in BEAS-2B cells. BEAS-2B cells were stimulated with medium, HRV-16, TGF- $\beta_{1}$, HRV-16 + TGF- $\beta_{1}$, UV-HRV-16, or UV-HRV-16+TGF- $\beta_{1}$ for 120 h. a Representative western blot for E-cadherin. b Densitometry analysis for E-cadherin $(n=12)$. c Representative western blot for fibronectin. d Densitometry analysis for fibronectin $(n=12)$. Asterisk indicates significance for comparisons shown by Dunn's post-hoc analysis after KruskalWallis ANOVA. Hatchmark indicates synergy compared to the sum of responses to individual stimuli by Wilcoxon matched-pairs signed ranks test

recent report that $\mathrm{HRV}-39$ could induce EMT-like marker protein changes in regenerating, but not normal epithelial cell cultures [44].

The pleiotropic cytokine, TGF- $\beta_{1}$ has been reported to be a key initiator of EMT in profibrotic processes occurring in the airways in asthma [20, 23, 45], and levels of TGF- $\beta_{1}$ are elevated in the airways of both children and adults with asthma [24, 25]. Given the central role ascribed to TGF- $\beta_{1}$ in triggering EMT, we were surprised to observe that both serotypes of HRV tested were more effective than TGF- $\beta_{1}$ at inducing the loss of the epithelial phenotypic marker proteins, Ecadherin and cytokeratin-18. This data contrasts with prior reports of TGF- $\beta_{1}$ triggering the loss of epithelial markers in both BEAS-2B cells [23] and primary human airway epithelial cells [20]. The reasons for this discrepancy are unclear, although differences in culture medium and growth conditions could potentially explain the difference between our data and those of Doerner and colleagues who grew BEAS-2B cells in a keratinocyte culture medium [23]. It is not feasible that BEAS-2B cells used in our studies do not express receptors for TGF- $\beta_{1}$, given that this cytokine was clearly effective in inducing mesenchymal markers. Our data were consistent with those of Heijink and coworkers who also found that TGF- $\beta_{1}$ had only a modest effect on the loss of epithelial markers [46]. Nonetheless, to examine this issue further we used activin $\mathrm{A}$, another member of the TGF- $\beta$ superfamily that we have previously shown to be induced in both BEAS-2B and primary airway epithelial cells in response to HRV infection [16] as an alternative ligand for the TGF- $\beta$ receptor. Consistent with the data obtained using TGF$\beta_{1}$, activin A also caused only a modest loss of Ecadherin but synergized with HRV-16 in inducing loss of this epithelial marker. 

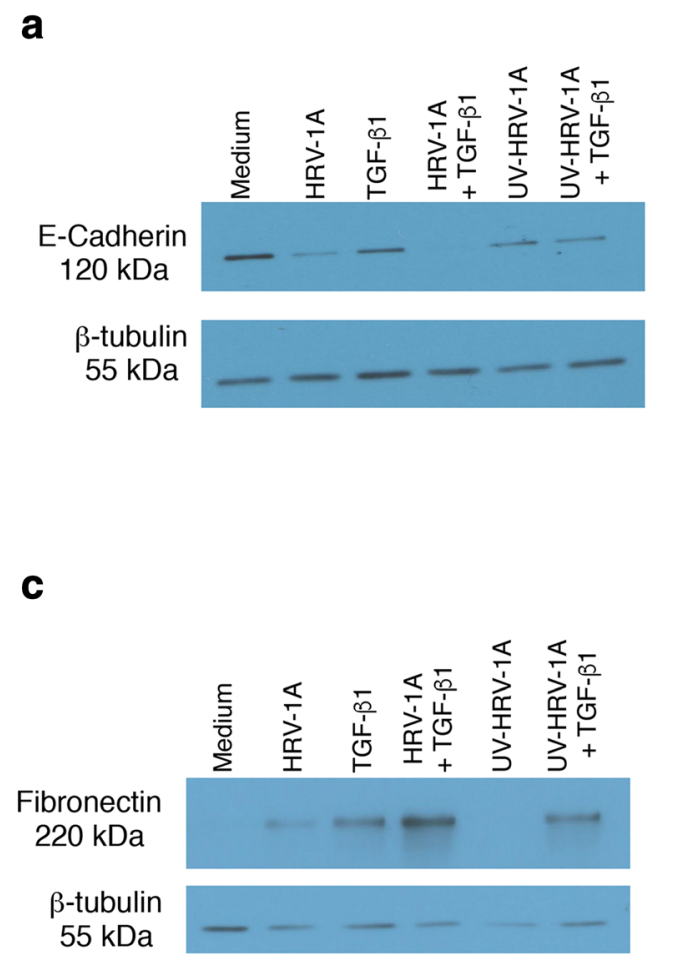

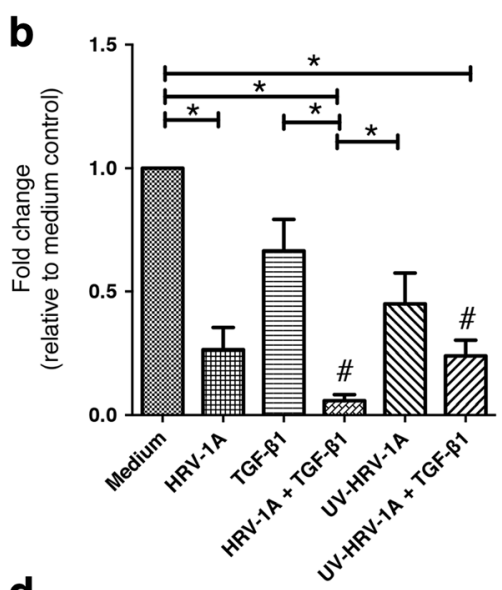

d

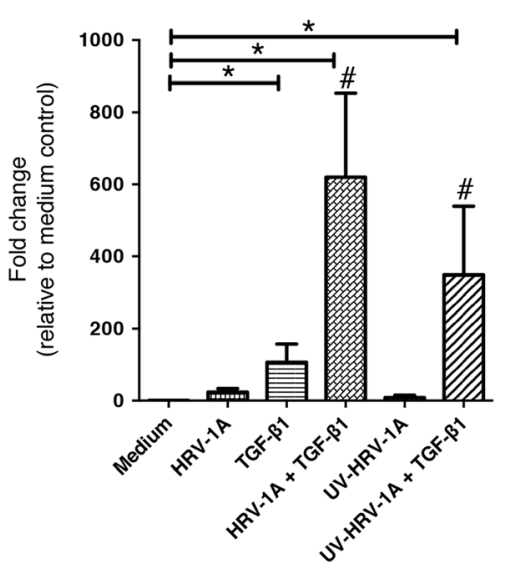

Fig. 7 The minor group HRV-1A, alone and in combination with TGF- $\beta_{1}$, also alters expression of epithelial and mesenchymal markers in BEAS-2B cells and effects do not depend upon viral replication. BEAS-2B cells were stimulated with medium, HRV-1A, TGF- $\beta_{1}, \mathrm{HRV}-1 \mathrm{~A}+\mathrm{TGF}-\beta_{1}, \mathrm{UV}-\mathrm{HRV}-1 \mathrm{~A}$, or UV-HRV-1A + TGF- $\beta_{1}$ for $120 \mathrm{~h}$. a Representative western blot for E-cadherin. b Densitometry analysis for E-cadherin $(n=6)$. c Representative western blot for fibronectin. d Densitometry analysis for fibronectin $(n=6)$. Asterisk indicates significance for comparisons shown by Dunn's posthoc analysis after Kruskal-Wallis ANOVA. Hatchmark indicates synergy compared to the sum of responses to individual stimuli by Wilcoxon matched-pairs signed ranks test

It is not clear why exposure to HRV is so effective in downregulating epithelial markers. One possible explanation relates to observations that, in addition to triggering some of the signal pathways studied in the current work, both the major (ICAM-1) and minor (LDLreceptor) HRV receptors are known to be associated with lipid rafts [47], which, in turn, are known to associated with the actin cytoskeleton [48]. Indeed, it has been known for some time that ICAM-1 is associated with the actin cytoskeleton [49]. More recently, it has been shown that binding of HRV to ICAM-1 is known to recruit the cytoskeletal linker protein ezrin to ICAM-1 [37]. Thus binding of HRV to it receptor (ICAM-1 or LDLR) likely leads to rearrangements in the actin cytoskeleton and/or microtubules, as has been shown for other picornaviruses [50]. Since the actin cytoskeleton is integral to the retention of an epithelial phenotype, and since cytokeratin and junctional proteins, such as E-cadherin, are closely affiliated with the actin cytoskeleton, this may lead to an increased capacity of HRV to induce loss of these epithelial markers, setting the stage for mesenchymal transition.

In contrast to data for epithelial markers, TGF- $\beta_{1}$ alone was more effective than either serotype of HRV alone in inducing expression of the mesenchymal markers, fibronectin and vimentin. There was a clear interaction between the two stimuli, however, as the combination of HRV and TGF- $\beta_{1}$ clearly induced synergistic changes in both epithelial and mesenchymal markers. The combination of HRV and TGF- $\beta_{1}$ was also most effective in causing morphological changes consistent with EMT. This is the first demonstration of an interaction between HRV and TGF- $\beta_{1}$ in causing EMTlike changes, but our data show some similarities to those of Heijink and co-workers, who also found that TGF- $\beta_{1}$ had only modest effects on reducing expression of epithelial markers, but synergized with house dust 
a

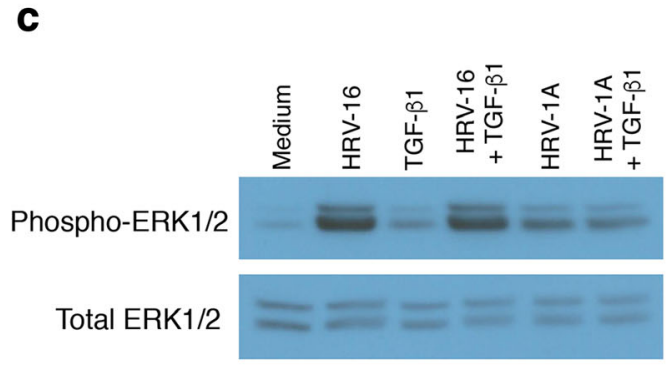

b

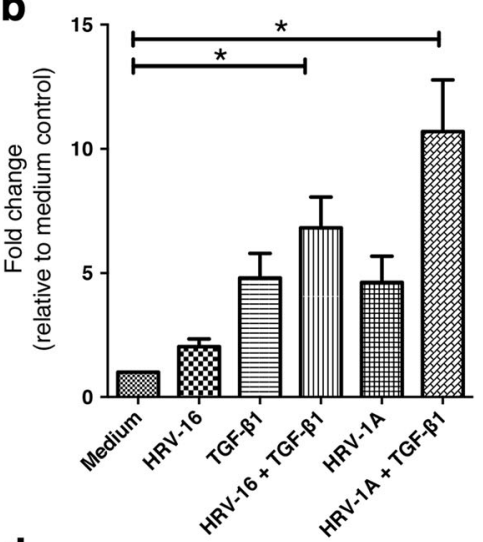

d

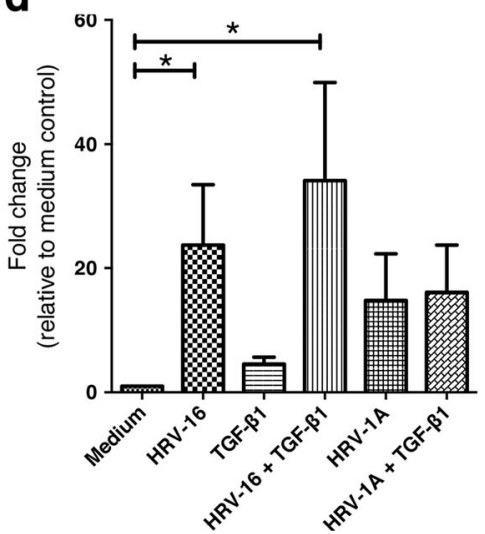

Fig. 8 Major and minor group HRV strains, and TGF- $\beta_{1}$, differentially activate MAPK signaling pathways. BEAS-2B cells were stimulated with medium, HRV-16, HRV-1A, TGF- $\beta_{1}$, HRV-16 + TGF- $\beta_{1}$, or HRV-1A + TGF- $\beta_{1}$ for 1 h. a Representative western blot for phospho- and total p38. b Densitometry analysis for p38 $(n=7)$. c Representative western blot for phospho and total ERK1/2. d Densitometry analysis for ERK1/2 $(n=5)$. Asterisk indicates significance for comparisons shown by Dunn's post-hoc analysis after Kruskal-Wallis ANOVA

mite to induce changes consistent with EMT [46]. Moreover, TGF- $\beta_{1}$ has also been reported to synergize with nicotine to induce EMT [51].

EMT is generally considered to be a slow and progressive process, with intermediate stages in which cells have the characteristics of both epithelial and mesenchymal cells [52]. It was unexpected, therefore, to find that changes associated with EMT, and interactions with TGF- $\beta_{1}$, could already be observed within $24 \mathrm{~h}$ of HRV exposure, and to find that viral replication was not required for HRV to exert its effects. This implied a role for early, receptor-dependent signaling, rather than replication dependent signaling through double stranded RNA pattern recognition receptors. Given that both major and minor group HRV serotypes induced phenotypic changes, relevant signals must be sent via either ICAM-1 or LDLR. Because little is known about early signaling through LDLR, we examined activation of the p38 and ERK1/2 MAPK pathways, as these are known to be activated both by TGF- $\beta_{1}[53,54]$, and via ICAM-1 signaling [37, 41, 42], to determine if these may also contribute to signaling via the LDLR. As expected, HRV-16 and TGF- $\beta_{1}$ each induced activation of the p38 MAPK pathway and we also provide the first evidence that HRV-1A also induced $\mathrm{p} 38$ activation. The combination of each serotype of HRV with TGF- $\beta_{1}$ led to an approximately additive activation in each case. Despite a prior report of ERK1/2 activation by TGF- $\beta_{1}$ in intestinal epithelial cells [54], TGF- $\beta_{1}$ alone did not induce appreciable activation of the ERK1/2 pathway in BEAS-2B cells. As expected, HRV-16 induced robust activation of ERK1/2 and this was slightly enhanced in the presence of TGF- $\beta_{1}$. By contrast, HRV-1A was considerably less effective in activation of ERK1/2 and there was no additional response in the presence of TGF- $\beta_{1}$.

To determine the potential role of MAPK pathways in EMT induced by HRV and TGF- $\beta_{1}$, selective 

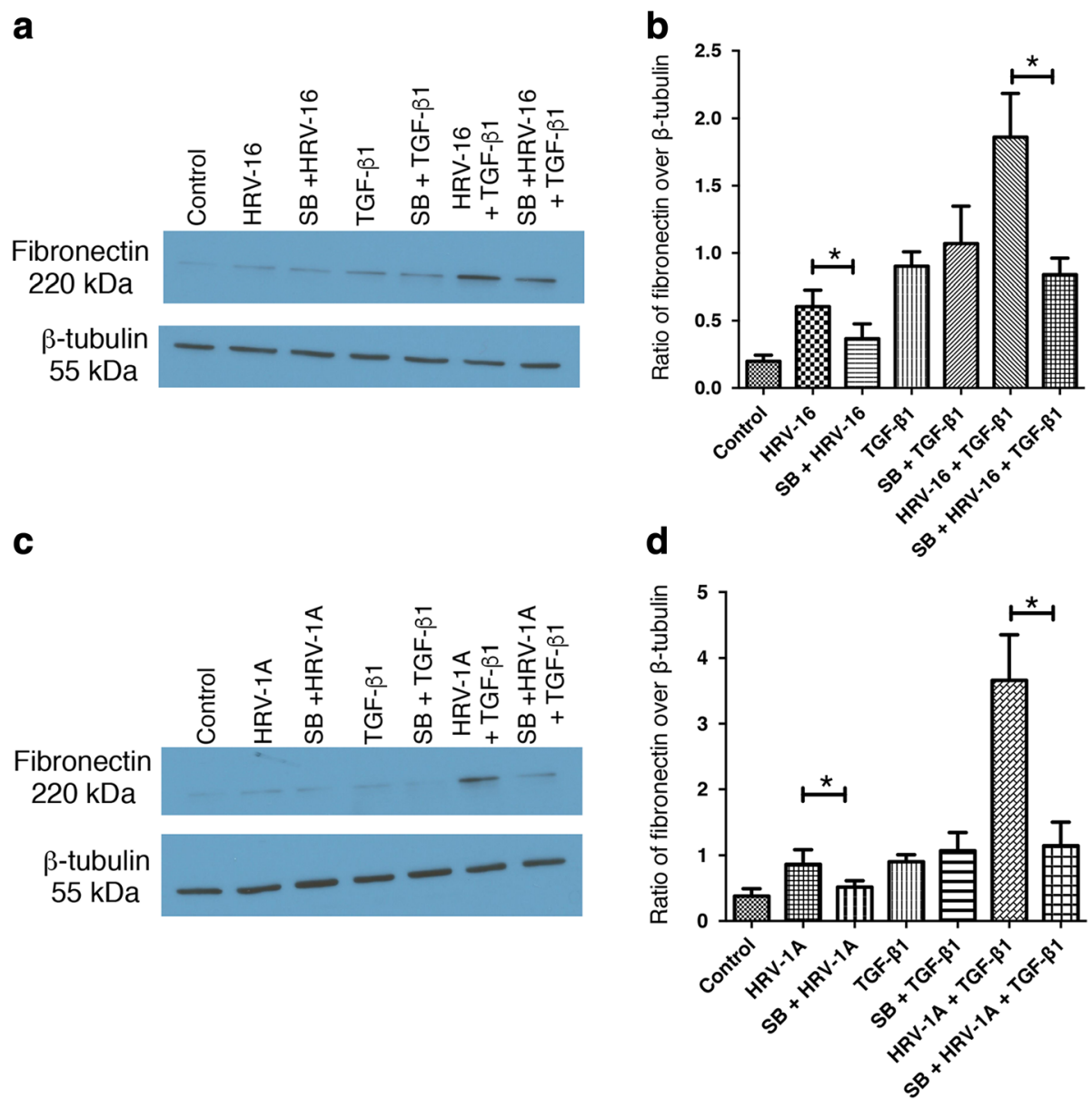

Fig. 9 Inhibition of the p38 MAPK pathway significantly inhibits the induction of fibronectin by each HRV seroptype alone and in combination with TGF- $\beta_{1}$. BEAS-2B cells were pre-treated for $1 \mathrm{~h}$ with the p38 MAPK pathway inhibitor, SB203580 (SB), and then stimulated with medium, HRV16, HRV-1A, TGF- $\beta_{1}$, HRV-16 + TGF- $\beta_{1}$, or HRV-1A + TGF- $\beta_{1}$ for 24 h. a Representative western blot for fibronectin using HRV-16 with and without SB. b Densitometry analysis for fibronectin using HRV-16 with and without SB. $(n=6)$. c Representative western blot for fibronectin using HRV-1A with and without SB. $\mathbf{d}$ Densitometry analysis for fibronectin using HRV-1A with and without SB. $(n=6)$. Asterisk indicates significance for comparisons shown by Dunn's post-hoc analysis after Kruskal-Wallis ANOVA

inhibitors of each pathway were used to examine effects on fibronectin expression. Inhibition of the p38 pathway significantly inhibited fibronectin expression induced by either serotype of HRV alone, and in combination with TGF- $\beta_{1}$. Surprisingly, inhibition of this pathway had little effect on responses to TGF- $\beta_{1}$ alone. Although TGF- $\beta_{1}$ did not induce a marked activation of ERK1/2, inhibition of this pathway significantly reduced fibronectin induction in response to the combination of HRV-16 and TGF- $\beta_{1}$ without affecting the modest response to HRV-16 alone. Interestingly, fibronectin induction in response to HRV-1A, either alone or combined with TGF- $\beta_{1}$, was enhanced by inhibition of the ERK1/2 pathway. Thus the p38 MAPK pathway appears to play a role in induction of EMT by both major and minor group HRV strains, alone and in conjunction with TGF- $\beta_{1}$, but the ERK1/2 pathway exerts different effects depending upon the HRV strain receptor involved.

To further examine the underlying basis of the potential mechanisms by which HRV may interact with TGF- $\beta_{1}$ to induce EMT, we examined pathways implicated in TGF- $\beta_{1}$ signaling. We provide the first evidence that both HRV-16 and HRV-1A are not only able to induce expression of the E-cadherin transcriptional repressor, SLUG, but that the combination of each HRV serotype with TGF- $\beta_{1}$ induces activation of SLUG that is greater than that seen with TGF- $\beta_{1}$ alone. This provides a potential mechanism to support the reduced expression of E-cadherin seen with HRV alone, and the synergistic induction observed with the combination of HRV and TGF- $\beta_{1}$. Interestingly, consistent with an earlier report [44], while each HRV serotype appeared to modestly induce 


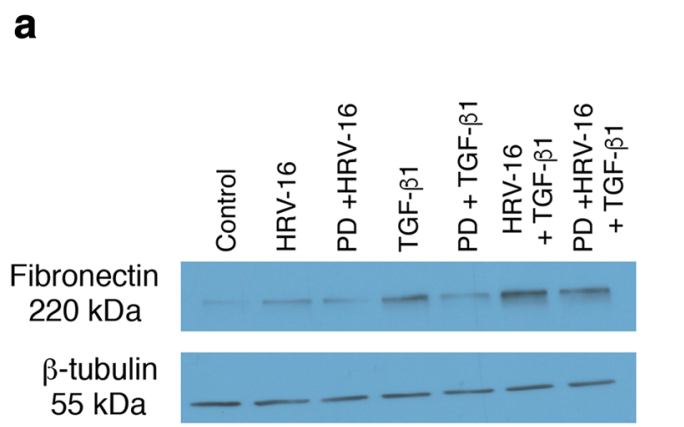

C

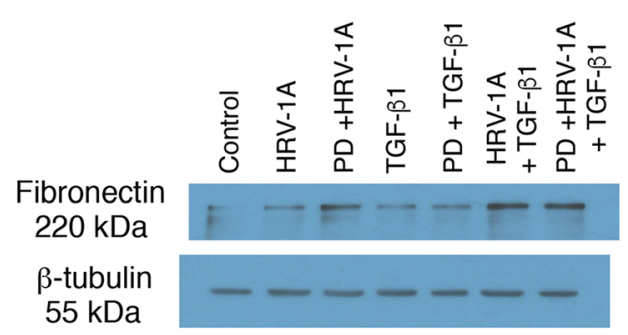

b

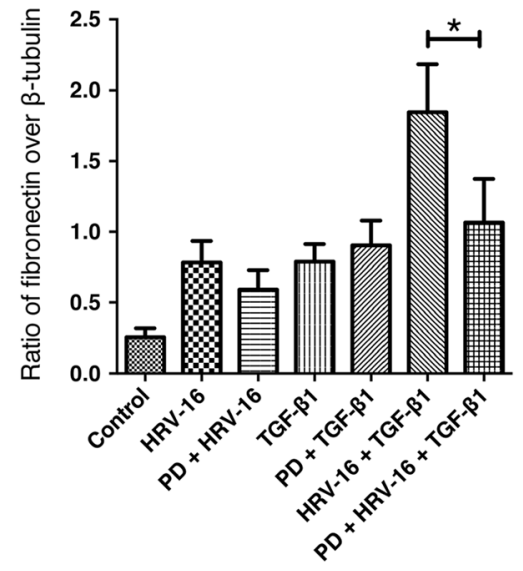

d

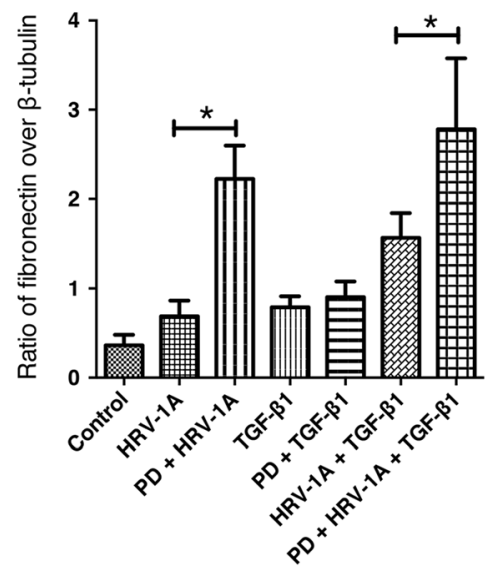

Fig. 10 Inhibition of the ERK/1/2 MAPK pathway differentially affects the induction of fibronectin by the combination of each HRV serotype with TGF$\beta_{1}$. BEAS-2B cells were pre-treated for $1 \mathrm{~h}$ with the ERK1/2 MAPK pathway inhibitor, PD98059 (PD), and then stimulated with medium, HRV-16, HRV-1A, TGF- $\beta_{1}$, HRV-16 + TGF- $\beta_{1}$, or HRV-1A + TGF- $\beta_{1}$ for $24 \mathrm{~h}$. a Representative western blot for fibronectin using HRV-16 with and without PD. b Densitometry analysis for fibronectin using HRV-16 with and without PD. $(n=6)$. c Representative western blot for fibronectin using HRV-1A with and without PD. d Densitometry analysis for fibronectin using HRV-1A with and without PD. $(n=6)$. Asterisk indicates significance for comparisons shown by Dunn's post-hoc analysis after Kruskal-Wallis ANOVA

activation of a second, related transcriptional repressor SNAIL, the combination of HRV and TGF- $\beta_{1}$ did not induce any activation above that observed with TGF- $\beta_{1}$ alone. Finally, we showed that neither HRV-16 nor HRV$1 \mathrm{~A}$ induced activation of the SMAD2/3 pathway, and the combination of either strain of virus with TGF- $\beta_{1}$ had no effect above that seen with TGF- $\beta_{1}$ alone.

A limitation of this study is the use of the BEAS-2B bronchial epithelial cell line. This was chosen because less than $10 \%$ of primary cells can be infected by major group HRV strains [26], raising concerns that insufficient "signal-to-noise" would be obtained. As noted, the BEAS-2B cell has been commonly used to examine EMT [23, 29-31], and has been shown to reproduce effects observed with HRV in primary cells in a number of studies [16, 55-57]. Nonetheless, it will be important to extend these studies to primary epithelial cells. This should be feasible having established that HRV-1A induced EMT as minor group HRV can infect a greater percentage of primary cells than major group strains [58]. It will also be important to determine if HRVinduced EMT is enhanced in epithelial cells from asthmatic children or adults.

It should be noted that, while EMT is a well-recognized process in both physiological and pathophysiological conditions, it remains unclear what percentage of fibroblasts and myofibroblasts in the asthmatic airways derive from EMT. Studies using genetic fate tracking of lung epithelial cells in a mouse model of allergic asthma reported that approximately $30 \%$ of murine lung fibroblasts were derived from epithelial cells that underwent EMT [59], but it is far from clear if this is the case in humans. 


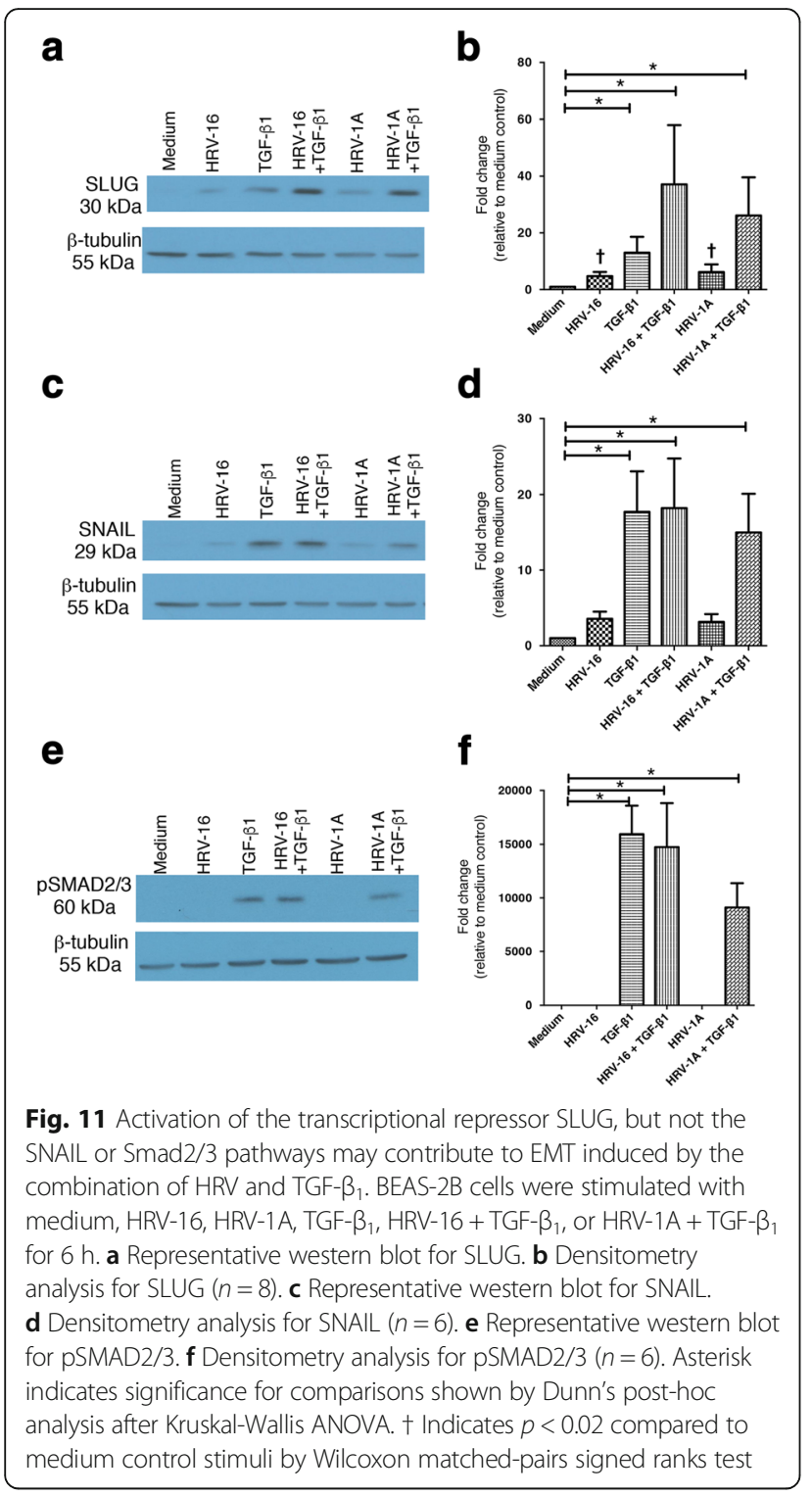

\section{Conclusions}

In summary, we provide the first evidence that both HRV-16 and HRV-1A, representing major group and minor group serotypes, respectively, are able to induce phenotypic and morphological changes in bronchial epithelial cells that are consistent with EMT. HRV appears to play a greater role in the loss of epithelial markers, but both serotypes of HRV synergize with TGF- $\beta_{1}$ to induce changes in epithelial and mesenchymal markers and to change morphology. The effects of HRV on EMT do not depend on viral replication but appear to involve activation of MAPK pathways, as well as activation of the transcriptional repressor SLUG. Taken together, our data add further support for the concept that repeated HRV infections may contribute to the development and progression of airway remodeling in asthma.

\section{Acknowledgements}

Not applicable.

\section{Funding}

Grant number 43923 from the Canadian Institutes of Health Research (CIHR) supported this work. Dr. Proud is the recipient of a Tier 1 Canada Research Chair in Inflammatory Airway Diseases. The funding body played no role in the design of the study; in the collection, analysis and interpretation of the date; in writing the manuscript; or in the decision to submit for publication.

\section{Availability of data and materials}

The authors' unpublished data are available upon request.

\section{Authors' contributions}

DMM and DP conceived of the project. DMM performed all experiments. DMM and DP both performed data analysis and interpretation. DMM wrote the initial draft of the manuscript. DP performed all final editing. Both authors read and approved the final manuscript for submission.

\section{Competing interests}

DMM has no competing interests in this manuscript. DP has received consulting fees from AstraZeneca, Janssen, Pfizer and Procter \& Gamble, and has received research grants from AstraZeneca and Medlmmune. None of these applied to the current work.

\section{Consent for publication \\ Not applicable.}

Ethics approval and consent to participate

Not applicable.

\section{Publisher's Note}

Springer Nature remains neutral with regard to jurisdictional claims in published maps and institutional affiliations.

\section{Author details}

${ }^{1}$ Department of Physiology \& Pharmacology, Snyder Institute for Chronic Diseases, Cumming School of Medicine, University of Calgary, Calgary, Alberta, Canada. ${ }^{2}$ University of Calgary, Faculty of Medicine, HRIC 4C50-54, 3280 Hospital Drive N.W., Calgary, AB T2N 4Z6, Canada. ${ }^{3}$ Department of Physiology \& Pharmacology, HRIC 4AC60, University of Calgary Cumming School of Medicine, 3280 Hospital Drive NW, Calgary, Alberta T2N 4Z6, Canada.

Received: 12 April 2017 Accepted: 24 May 2017

Published online: 30 May 2017

\section{References}

1. Al-Muhsen S, Johnson JR, Hamid Q. Remodeling in asthma. J Allergy Clin Immunol. 2011;128:451-62.

2. Jeffery PK. Remodeling and inflammation of bronchi in asthma and chronic obstructive pulmonary disease. Proc Am Thorac Soc. 2004;1:176-83.

3. Benayoun L, Druilhe A, Dombret M-C, Aubier M, Pretolani M. Airway structural alterations selectively associated with severe asthma. Am J Respir Crit Care Med. 2003;167:1360-8.

4. Brewster CEP, Howarth PH, Djukanovic R, Wilson J, Holgate ST, Roche wR. Myofibroblasts and subepithelial fibrosis in bronchial asthma. Am J Respir Cell Mol Biol. 1990;3:507-11.

5. Pohunek P, Warner JO, Turzíková J, Kudrmann J, Roche WR. Markers of eosinophilic inflammation and tissue re-modelling in children before clinically diagnosed bronchial asthma. Pediatr Allergy Immunol. 2005;16:43-51.

6. Saglani S, Payne DN, Zhu J, Nicholson AG, Bush A, Jeffery PK. Early detection of airway wall remodeling and eosinophilic inflammation in preschool wheezers. Am J Respir Crit Care Med. 2007;176:858-64.

7. Payne DN, Rogers AV, Adelroth E, Bandi V, Guntupalli KK, Bush A, Jeffery PK. Early thickening of the reticular basement membrane in children with difficult asthma. Am J Respir Crit Care Med. 2003;167:78-82.

8. O'Reilly R, Ullmann N, Irving S, Bossley CJ, Sonnappa S, Zhu J, Oates T, Banya W, Jeffery PK, Bush A, Saglani S. Increased airway smooth muscle in preschool wheezers who have asthma at school age. J Allergy Clin Immunol. 2013;131:1024-32. 
9. Lezmi G, Gosset P, Deschildre A, Abou-Taam R, Mahut B, Beydon N, de Blic J. Airway remodeling in preschool children with severe recurrent wheeze. Am J Respir Crit Care Med. 2015;192:164-71.

10. Saglani S, Malmström K, Pelkonen AS, Mamberg P, Lindahl H, Kajosaari M, Turpeinen M, Rogers AV, Payne DN, Bush A, Haahtela T, Mäkelä MJ, Jeffery PK. Airway remodeling and inflammation in symptomatic infants with reversible airflow obstruction. Am J Respir Crit Care Med. 2005;171:722-7.

11. Lemanske Jr RF, Jackson DJ, Gangnon RE, Evans MD, Li Z, Shult PA, Kirk CJ, Reisdorf E, Roberg KA, Anderson EL, Carlson-Dakes KT, Adler KJ, GilbertsonWhite S, Pappas TE, DaSilva DF, Tisler CJ, Gern JE. Rhinovirus illnesses during infancy predict subsequent childhood wheezing. J Allergy Clin Immunol. 2005;116:571-7.

12. Kotaniemi-Syrjänen $A$, Vainionpää R, Reijonen TM, Waris M, Korhonen K, Korppi M. Rhinovirus-induced wheezing in infancy-the first sign of childhood asthma? J Allergy Clin Immunol. 2003;111:66-71.

13. Jackson DJ, Gangnon RE, Evans MD, Roberg KA, Anderson EL, Pappas TE, Printz MC, Lee W-M, Shult PA, Reisdorf E, Carlson-Dakes KT, Salazar LP, DaSilva DF, Tisler CJ, Gern JE, Lemanske Jr RF. Wheezing rhinovirus illnesses in early life predict asthma development in high-risk children. Am J Respir Crit Care Med. 2008;178:667-72.

14. Winther B, Hayden FG, Hendley JO. Picornavirus infection in children diagnosed by RT-PCR during longitudinal surveillance with weekly sampling: association with symptomatic illness and effect of season. J Med Virol. 2006;78:644-50.

15. Jartti T, Lee W-M, Pappas T, Evans M, Lemanske Jr RF, Gern JE. Serial viral infections in infants with recurrent respiratory illnesses. Eur Respir J. 2008; 32:314-20.

16. Leigh R, Oyelusi W, Wiehler S, Koetzler R, Zaheer RS, Newton R, Proud D. Human rhinovirus infection enhances airway epithelial cell production of growth factors involved in airway remodeling. J Allergy Clin Immunol. 2008; 121:1238-45.

17. Tacon CE, Wiehler S, Holden NS, Newton R, Proud D, Leigh R. Human rhinovirus infection of airway epithelial cells upregulates MMP-9 production via NF-kB. Am J Respir Cell Mol Biol. 2010;43:201-9.

18. Psarras S, Volonaki E, Skevaki CL, Xatzipsalti M, Bossios A, Pratsinis H, Tsigkos S, Gourgiotis D, Constantopoulos AG, Papapetropoulos A, Saxoni-Papageorgiou P, Papadopoulos NG. Vascular endothelial growth factor-mediated induction of angiogenesis by human rhinovirus. J Allergy Clin Immunol. 2006;117:291-7.

19. Iwano M, Plieth D, Danoff TM, Xue C, Okada H, Neilson EG. Evidence that fibroblasts derive from epithelium during tissue fibrosis. J Clin Invest. 2002; 110:341-50.

20. Hackett T-L, Warner SM, Stafanowicz D, Shaheen F, Pechkovsky DV, Murray LA, Argentieri R, Kicic A, Stick SM, Bai TR, Knight DA. Induction of epithelialmesenchymal transition in primary airway epithelial cells from patients with asthma by transforming growth factor- $\beta 1$. Am J Respir Crit Care Med. 2009; 180:122-33.

21. Willis BC, Liebler JM, Luby-Phelps K, Nicholson AG, Crandall ED, du Bois RM, Borok Z. Induction of epithelial-mesenchymal transition in alveolar epithelial cells by transfrming growth factor-beta1: potential role in idiopathic pulmonary fibrosis. Am J Pathol. 2005;166:1321-32.

22. Kim KK, Kugler MC, Wolters PJ, Robillard L, Galvez MG, Brumwell AN, Sheppard D, Chapman HA. Alveolar epithelial cell mesenchymal transition develops in vivo during pulmonary fibrosis and is regulated by extracellular matrix. Proc Natl Acad Sci U S A. 2006;103:13180-5.

23. Doerner AM, Zuraw BL. TGF- $\beta 1$ induced epithelial to mesenchymal transition (EMT) in human bronchial epithelial cells is enhanced by IL-1 $\beta$ but not abrogated by corticosteroids. Respir Res. 2009;10:100.

24. Redington AE, Madden J, Frew AJ, Djukanovic R, Roche W, Holgate ST, Howarth PH. Transforming growth factor- $\beta 1$ in asthma. Measurement in bronchoalveolar lavage fluid. Am J Respir Crit Care Med. 1997;156:642-7.

25. Vignola AM, Chanez P, Chiappara G, Merendino A, Pace E, Rizzo A, la Rocca AM, Bellia V, Bonsignore G, Bousquet J. Transforming growth factor- $\beta$ expression in mucosal biopsies in asthma and chronic bronchitis. Am J Respir Crit Care Med. 1997;156:591-9.

26. Mosser AG, Brockman-Schneider R, Amineva S, Burchell L, Sedgewick JB, Busse WW, Gern JE. Similar frequency of rhinovirus-infectable cells in upper and lower airway epithelium. J Infect Dis. 2002;185:734-43.

27. Subauste MC, Choi D-C, Proud D. Transient exposure of human bronchial epithelial cells to cytokines leads to persistent increased expression of ICAM-1. Inflammation. 2001;25:373-80.

28. Reddel RR, Ke Y, Gerwin BI, McMenamin MG, Lechner JF, Su RT, Brash DE, Park J-B, Rhim JS, Harris CC. Transformation of human bronchial epithelial cells by infection with SV40 or adenovirus-12 SV40 hybrid virus, or transfection via strontium phosphate coprecipitation with a plasmid containing SV40 early region genes. Cancer Res. 1988;48:1904-9.

29. Hosper NA, van den Berg PP, de Rond S, Popa ER, Wilmer MJ, Masereeuw R, Bank RA. Epithelial-to-mesenchymal transition in fibrosis: collagen type I expression is highly upregulated after EMT, but does not contribute to collagen deposition. Exp Cell Res. 2013;319:3000-9.

30. Hosoki K, Kainuma K, Toda M, Harada E, Chelakkot-Govindalayathila AL, Roeen Z, Nagao M, D’Alessandro-Gabazza CN, Fujisawa T, Gabazza EC. Montelukast suppresses epithelial to mesenchymal transition of bronchial epithelial cells induced by eosinophils. Biochem Biophys Res Commun. 2014:449:351-6.

31. Itoigawa Y, Harada N, Harada S, Katsura Y, Makino F, Ito J, Nurwidya F, Kato M, Takahashi F, Atsuta R, Takahashi K. TWEAK enhances TGF- $\beta$-induced epithelial-mesenchymal transition in human bronchial epithelial cells. Respir Res. 2015;16:48.

32. Subauste MC, Jacoby DB, Richards SM, Proud D. Infection of a human respiratory epithelial cell line with rhinovirus. Induction of cytokine release and modulation of susceptibility to infection by cytokine exposure. J Clin Invest. 1995;96:549-57.

33. Unger BL, Faris AN, Ganesan S, Comstock AT, Hershenson MB, Sajjan US. Rhinovirus attenuates non-typeable Haemophilus influenza-stimulated IL-8 responses via TLR2-dependent degradation of IRAK-1. PLoS Pathog. 2012;8: e1002969.

34. Eddleston J, Lee RU, Doerner AM, Herschbach J, Zuraw BL. Cigarette smoke decreases the innate responses of epithelial cells to rhinovirus infection. Am J Respir Cell Mol Biol. 2011;44:118-26.

35. Gern JE, Dick EC, Lee WM, Murray S, Meyer K, Handzel ZT, Busse WW. Rhinovirus enters but does not replicate inside monocytes and airway macrophages. J Immunol. 1996;156:621-7.

36. Sanders SP, Siekierski ES, Porter JD, Richards SM, Proud D. Nitric oxide inhibits rhinovirus-induced cytokine production and viral replication in a human respiratory epithelial cell line. J Virol. 1998;72:934-42.

37. Wang X, Lau C, Wiehler S, Pow A, Mazzulli T, Gutierrez C, Proud D, Chow C-W. Syk is downstream of intercellular adhesion molecule-1 and mediates human rhinovirus activation of p38 MAPK in airway epithelial cells. J Immunol. 2006;177:6859-70.

38. Lau C, Wang X, Song L, North M, Wiehler S, Proud D, Chow C-W. Syk associates with clathrin and mediates phosphatidylinositol 3-kinase activation during human rhinovirus internalization. J Immunol. 2008;180:870-80.

39. Bentley JK, Newcomb DC, Goldsmith AM, Jia Y, Sajjan US, Hershenson MB. Rhinovirus activates interleukin-8 expression via a Src/p110 $\beta$ phosphatylinositol 3-kinase pathway in human airway epithelial cells. J Virol. 2007;81:1186-94.

40. Newcomb DC, Sajjan U, Nanua S, Jia Y, Goldsmith AM, Bentley JK, Hershenson MB. Phosphatidylinositol 3-kinase is required for rhinovirus-induced airway epithelial cell interleukin-8 expression. J Biol Chem. 2005;280:36952-61.

41. Wiehler S, Proud D. Interleukin-17A modulates human airway epithelial responses to human rhinovirus infection. Am J Physiol Cell Mol Physiol. 2007;293:L505-15.

42. Zaheer RS, Koetzler R, Holden NS, Wiehler S, Proud D. Selective transcriptional down-regulation of human rhinovirus-induced production of CXCL10 from airway epithelial cells via the MEK1 pathway. J Immunol. 2009;182:4854-64.

43. Shelfoon C, Shariff S, Traves SL, Kooi C, Leigh R, Proud D. Chemokine release from human rhinovirus-infected airway epithelial cells promotes fibroblast migration. J Allergy Clin Immunol. 2016;138:110-22.

44. Faris AN, Ganesan S, Chattoraj A, Chattoraj SS, Comstock AT, Unger BL, Hershenson MB, Sajjan US. Rhinovirus delays cell repolarization in a model of injured/regenerating human airway epithelium. Am J Respir Cell Mol Biol. 2016; 55:487-99.

45. Minshall EM, Leung DYM, Martin RJ, Song YL, Cameron L, Ernst P, Hamid Q. Eosinophil-associated TGF- $\beta 1$ mRNA expression and airways fibrosis in bronchial asthma. Am J Respir Cell Mol Biol. 1997;17:326-33.

46. Heijink IH, Postma DS, Noordhoek JA, Broekema M, Kapus A. House dust mite-promoted epithelial to mesenchymal transition in human bronchial epithelium. Am J Respir Cell Mol Biol. 2010;42:69-79.

47. Blaas D. Viral entry pathways: the example of common cold viruses. Wien Med Wochenscr. 2016;166:211-26.

48. Chichili GR, Rodgers W. Cytoskeleton-membrane interactions in membrane raft structure. Cell Mol Life Sci. 2009;66:2319-28.

49. Carpén $O$, Pallai P, Staunton DE, Springer TA. Association of intercellular adhesion molecule-1 (ICAM-1) with actin-containing cytoskelatin and aactinin. J Cell Biol. 1992;118:1223-34. 
50. Armer H, Moffat K, Wileman T, Belsham GJ, Jackson T, Duprex WP, Ryan M, Monaghan P. Foot-and-mouth disease virus, but not bovine enterovirus, targets the host cell cytoskeleton via the nonstructuralprotein $3 \mathrm{C}^{\mathrm{prov}}$. J Virol. 2008;82:10556-66.

51. Zou W, Zou Y, Zhao Z, Li B, Ran P. Nicotine-induced epithelial-mesenchymal transition via Wnt/B-catenin signaling in human airway epithelial cells. Am J Physiol Lung Cell Mol Physiol. 2013;304:L199-209.

52. Bartis D, Mise N, Mahida RY, Eickelberg O, Thickett DR. Epithelialmesenchymal transition in lung development and disease: does it exist and is it important? Thorax. 2014;69:760-5.

53. Bakin AV, Rinehart C, Tomlinson AK, Arteaga CL. p38 mitogen activated protein kinase is required for TGF $\beta$-mediated fibroblastic differentiation and cell migration. J Cell Sci. 2002;115:3193-206.

54. Hartsough MT, Mulder KM. Transforming growth factor $\beta$ activation of p44mapk in proliferating cultures of epithelial cells. J Biol Chem. 1995;270:7117-24.

55. Hudy MH, Traves SL, Wiehler S, Proud D. Cigarette smoke modulates rhinovirus-induced airway epithelial chemokine production. Eur Respir J. 2010;35:1256-63.

56. Khaitov MR, Laza-Stanca V, Edwards MR, Walton RP, Rohde G, Contoli M, Papi A, Stanciu LA, Kotenko SV, Johnston SL. Respiratory virus induction of alpha-, beta, and lambda-interferons in bronchial epithelial cells and peripheral blood mononuclear cells. Allergy. 2009;64:375-86.

57. Wang Q, Nagarkar DR, Bowman ER, Schneider D, Gosangi B, Lei J, Zhao Y, McHenry CL, Burgens RV, Miller DJ, Sajjan US, Hershenson MB. Role of double-stranded RNA pattern recognition receptors in rhinovirus-induced airway epithelial cell responses. J Immunol. 2009;183:6989-97.

58. Konno S, Grindle KA, Lee W-M, Schroth MK, Mosser AG, Brockman-Schneider RA, Busse WW, Gern JE. Interferon- $y$ enhances rhinovirus-induced RANTES secretion by airway epithelial cells. Am J Respir Cell Mol Biol. 2002;26:594-601.

59. Johnson JR, Roos A, Berg T, Nord M, Fuxe J. Chronic respiratory aeroallergen exposure in mice induces epithelial-mesenchymal transition in the large airways. PLoS One. 2011;6:e16175.

\section{Submit your next manuscript to BioMed Central and we will help you at every step:}

- We accept pre-submission inquiries

- Our selector tool helps you to find the most relevant journal

- We provide round the clock customer support

- Convenient online submission

- Thorough peer review

- Inclusion in PubMed and all major indexing services

- Maximum visibility for your research

Submit your manuscript at www.biomedcentral.com/submit 